\title{
UPAYA GURU MENGEMBANGKAN KECERDASAN INTRAPERSONAL ANAK USIA DINI MELALUI SENTRA MAIN PERAN di TA AL-MANNAR PONOROGO
}

\author{
Murni Nur Ikasari \\ Institut Agama Islam Negeri Ponorogo \\ Email: nurikasari75@gmail.com
}

\begin{abstract}
Abatrak: The purpose of this research is to find out more deeply the steps taken by the TA Al-Manaar Al-Islamiyah Wali Songo Islamic Boarding School Ngabar Siman Ponorogo in developing intrapersonal intelligence of early childhood through role playing centers, as well as seeing the results achieved from the steps for the development of intrapersonal intelligence of early childhood, and do not forget to know the obstacles or obstacles faced by the implementation of these steps. This type of research is a qualitative research method or case study approach. Data analysis techniques are data reduction, data presentation, conclusion drawing or data verification. The results achieved by intrapersonal intelligence of early childhood in TA Al-Manaar Al-Islamiyah Ngabar have been well developed through the activities center playing roles with indicators such as self-awareness, emotional control, obeying the rules, a sense of responsibility has also been well developed. Barriers that arise, there are still children who are shy in playing a role, it takes a long time to play a role and the lack of supporting facilities in the center of role playing.
\end{abstract}

Keywords: Children, Intrapersonal, role playing

\begin{abstract}
Abatrak: Tujuan penelitian ini untuk mengetahui secara lebih mendalam langkahlangkah yang dilakukan guru TA Al-Manaar Al-Islamiyah Pondok Pesantren Wali Songo Ngabar Siman Ponorogo dalam mengembangkan kecerdasan intrapersonal anak usia dini melalui sentra main peran, serta melihat hasil yang telah dicapai dari langkah tersebut bagi pengembangan kecerdasan intrapersonal anak usia dini, dan tak lupa untuk mengetahui kendala atau hambatan yang dihadapi dari penerapan langkah tersebut. Jenis penelitian ini adalah penelitian kualitatif dengan metode atau pendekatan study kasus (Case study). Teknik analisis data yaitu reduksi data, penyajian data, penarikan kesimpulan atau verifikasi data. Hasil yang dicapai kecerdasan intrapersonal anak usia dini di TA Al-Manaar Al-Islamiyah Ngabar sudah berkembang dengan baik melalui kegiatan sentra main peran dengan indikator seperti kesadaran diri, pengendalian emosi, menaati aturan, rasa tanggung jawab juga sudah berkembang dengan baik. Hambatan yang muncul, masih ada anak yang malu dalam memainkan peran, butuh waktu lama untuk main peran dan kurangnya fasilitas penunjang dalam sentra main peran.

Kata kunci: Anak, Intrapersonal, main peran
\end{abstract}

\section{PENDAHULUAN}

Pendidikan Anak Usia Dini (PAUD) pada hakikatnya terkait erat dengan istilah guru. Guru diidentifikasi sebagai seorang yang memiliki kharisma atau wibawa untuk ditiru dan diteladani. Guru juga dipandang sebagai orang dewasa yang bertanggung jawab dalam mendidik, mengajar dan membimbing anak, juga sebagai orang yang memiliki kemampuan untuk mengajar dan menata kelas. Dalam hal ini guru adalah 
suatu jabatan atau profesi yang memerlukan keahlian khusus.Sesuai peraturan Menteri Nasional Nomor 58 Tahun 2009 tentang Standar Pendidikan Anak Usia Dini di Indonesia bab III tentang Standar Pendidik dan Kependidikan dinyatakan bahwa pendidik anak usia dini adalah tenaga profesional yang bertugas merencanakan, melaksanakan proses pembelajaran, dan menilai hasil pembelajaran, serta melakukan pembimbingan, pengasuhan dan perlindungan anak didik. Pendidik PAUD bertugas di berbagai jenis layanan baik pada jalur pendidikan formal maupun nonformal. ${ }^{1}$

Sebagai seorang pendidik yang memahami fungsi dan tugasnya, guru dibekali dengan berbagai ilmu keguruan sebagai dasar, disertai dengan latihan keterampilan keguruan.Beberapa kompetensi yang harus dimiliki oleh guru PAUD antara lain: guru mampu menguasai karakteristik peserta didik dari aspek fisik, moral, sosial, kultural, emosional, dan intelektual. Guru mampu mengembangkan kurikulum yang terkait dengan bidang pengembangan serta guru harus memiliki kemampuan menyelenggarakan kegiatan pengembangan yang mendidik bagi peserta didik. Kegiatan pengembangan dalam mendidik peserta didik harus selalu ditingkatkan agar guru mampu meningkatkan kualitas pembelajaran PAUD pada peserta didik sesuai dengan tahapan usianya.

Pendidikan Taman Kanak-Kanak (TK) ataupun Raudhatul Athfal (RA) harus diselenggarakan berdasarkan prinsip-prinsip yang telah ditetapkan. Penyelenggaraan pendidikan pada taman kanak-kanak berdasarkan prinsip-prinsip pendidikan anak usia dini sebagai berikut: 1) belajar melalui bermain; 2) berorientasi; 3) kegiatan belajar mengembangkan kecerdasan secara terpadu; 4) menggunakan pendekatan kelompok, klasikal dan individual; 5) lingkungan kondusif;6) menggunakan berbagai model pembelajaran; 7) mengembangkan

\footnotetext{
1 Mukhtar dkk, 2016,“Orientasi Baru Pendidikan Anak Usia Dini Teori dan Aplikasi”,Jakarta:Prenadamedia Group.
} 
keterampilan hidup dan hidup beragama; 8) menggunakan media dan sumber belajar; dan 9) pembelajaran yang berorientasi kepada prinsip perkembangan belajar anak usia dini. ${ }^{2}$

Pada umumnya orang tua tentunya menginginkan agar kelak anaknya tumbuh menjadi anak yang cerdas. Orang tua akan sangat bangga, ketika melihat anaknya yang masih berusia dini sudah mampu membaca, menulis dan berhitung dengan baik. Hal ini berarti, kata cerdas di masyarakat diartikan hanya sebatas pada kecerdasan Intelligence Quotient (IQ) saja, padahal terdapat berbagai macam kecerdasan. Berkenaan hal itu, dapat dipahami bahwa pada diri anak terdapat berbagai kecerdasan atau yang sering disebut kecerdasan jamak. Menurut Gardner sebagimana dikutip oleh Muhammad Yaumi dan Nurdin Ibrahim, kecerdasan jamak (Multiple intelligence) adalah berbagai keterampilan dan bakat yang dimiliki oleh siswa untuk menyelesaikan berbagai persoalan dalam pembelajaran ${ }^{3}$. Menurutnya, ada delapan kecerdasan yang terdapat pada diri manusia, meliputi: kecerdasan verbal, logis-matematik, visual-spasial, jasmaniah-kinestetik, berirama-musik, intrapersonal, interpersonal, dan naturalistik ${ }^{4}$. Setiap orang dapat mengembangkan semua kecerdasannya. Tidak ada anak yang bodoh atau pintar, yang ada hanya anak yang menonjol dalam salah satu atau beberapa jenis kecerdasan.

Salah satu kecerdasan yang dikembangkan pada Pendidikan Anak Usia Dini (PAUD) yaitu kecerdasan intrapersonal. Kecerdasan intrapersonal merupakan kemampuan untuk memahami dirinya sendiri dan bertanggung jawab atas apa yang ia perbuat. Kecerdasan intrapersonal juga diartikan kemampuan untuk memahami diri sendiri

\footnotetext{
${ }^{2}$ Ihsan El-Khuluqo, 2015, "Manajemen PAUD (Pendidikan Anak Usia Dini): Pendidikan Taman Kehidupan Anak", Yogyakarta: Pustaka Belajar. H.33-34

${ }^{3}$ Muhammad Yaumi dan Nurdin Ibrahim, 2013, "Pembelajaran berbasis kecerdasan jamak", Jakarta: Kencana Prenadamedia grup. H. 20

${ }^{4}$ Khodijah, 2012, “konsep dasar pendidikan prasekolah”, Medan: perdana mulya sarana. H. 4
} 
(keinginan dan maksud), memiliki kemampuan untuk mandiri dan efektif untuk memanfaatkan informasi ${ }^{5}$.Kecerdasan ini berupa kemampuan diri untuk berfikir secara reflektif, yaitu mengacu kepada kesadaran diri mengenai perasaan dan proses pemikiran dirinya sendiri. Sedangkan kegiatannya antara lain meditasi, mimpi, berdiam diri, perenungan, dan berimajinasi ${ }^{6}$.

Komponen inti yang ada didalam kecerdasan ini adalah kepekaan memahami perasaannya sendiri yang akurat dan kemampuan memahami emosi, memahami kelebihan dan kekurangan diri, kesadaran akan suasana hati, kehendak, motivasi, sifat, keinginan, serta kemampuan kedisiplinan diri. Orang dengan kecerdasan intrapersonal tinggi pada umumnya sangat mandiri dan yakin pada pendapat diri yang kuat pada hal-hal yang kontroversial. Mereka memiliki rasa percaya diri yang besar serta senang sekali melakukan hal dengan sendirinya?

Salah satu cara yang dapat dilakukan untuk mengembangkan kecerdasan intrapersonal anak usia dini adalah melalui kegiatan sentra bermain peran. Main peran merupakan salah satu permainan yang dilakukan dengan khayalan atau berpura-pura untuk memainkan suatu peran tertentu serta memungkinkan anak untuk mempelajari peran-peran sosial. Main peran juga bisa merangsang kecerdasan jamak anak dalam berekspresi dan berkomprehensi sekaligus ${ }^{8}$. Dalam sentra main peran anak berpura-pura menjadi orang lain, meniru perbuatan atau perkataan orang lain, mengambil peran dan menggunakan alat-alat rill atau imajinasi. Saat main peran, anak-anak belajar memecahkan setiap masalah yang

\footnotetext{
${ }^{5}$ Novi Mulyani, 2016, "Super Asyik Permainan Tradisional Anak Indonesia”, Yogyakarta: DIVA Press. H.37

${ }^{6}$ Evi Muafiah, 2016, "Strategi Pembelajaran Multiple Intelligences di TK/RA Ponorogo", Jurnal ThufuLA vol.4 No.1,https//:www.researchgat.net/publication/329780143, h.73

${ }^{7}$ Julia Jasmine, 2016, "Metode Mengajar Multiple Intelegences, penerjemah dari Julia Jasmine profesional's Guide: Teaching with Multiple Intelegences Teacher Created Materials, Inc. 2001. Bandung: Nuansa. H. 27-28

${ }^{8}$ Andrianus Krobo, 2014, “Jurnal Pendidikan Anak Usia Dini”, Vol. 8, Edisi 1.
} 
terjadi. Anak-anak mampu menciptakan situasi yang berkembang dan imajinasinya tentang tokoh yang diperankannya.

Dengan improvasi main peran, anak-anak belajar tentang kreatif yang penting bagi kehidupan sosialnya. Main peran menjadi penting untuk anak usia dini karena tidak disiapkan skripnya secara khusus. Main peran juga sangat penting untuk perkembangan kognisi, sosial dan emosional anak. Hal ini menjadi landasan bagi dasar perkembangan daya cipta, daya ingat, kerja sama kelompok, penyerapan kosa kata, konsep hubungan kekeluargaan, pengendalian diri, keterampilan memahami spasial dan afeksi ${ }^{9}$.

TA Al-Manaar Al-Islamiyah Pondok Pesantren Wali Songo Ngabar Siman Ponorogo adalah salah satu sekolah pendidikan anak usia dini yang telah berlangsung selama 57 tahun, dengan tingkat pengalaman yang telah matang dalam mendidik anak usia dini. Sekolah ini menggunakan model pembelajaran 5 macam sentra yaitu sentra persiapan 1, sentra persiapan 2, sentra bahan imtaq (iman dan taqwa), sentra bahan alam, dan sentra main peran. Dalam pelaksanaannya pembelajaran sentra tersebut anak secara mandiri memilih kegiatan yang disukai tetapi tetap dengan bimbingan guru. Selain itu anak juga diajarkan banyak hal seperti mengembalikan mainan ke tempatnya setelah menggunakannya, membuang sampah pada tempatnya, buang air kecil dan besar ke kamar mandi sendiri dan masih banyak lagi kegiatan intrapersonal (kemandirian, tanggung jawab dan lain-lain) yang diajarkan di sana. Banyak anak yang sudah baik dalam perkembangan kecerdasan intrapersonalnya, tetapi ada beberapa di kelas TK B1 yang masih belum maksimal perkembangan kecerdasan intrapersonalnya seperti tidak mau mengembalikan alat permainan pada tempatnya, menaruh sandal/sepatu

${ }^{9}$ Zakaria Hanafi, 2012, “Implementasi Metode Sentra Dalam Pengembangan Kecerdasan Majemuk Anak Usia Dini”, Yogyakarta: Deepublish. H. 94-97 
tidak pada tempatnya dan ada pula anak yang mengganggu temannya saat bermain (Hasil Observasi, Oktober 2019).

Berdasarkan temuan yang telah diuraikan di atas, peneliti merasa perlu mengadakan penelitian terkait upaya gurudalam mengembangkan kecerdasan intrapersonal anak usia dini melaluikegiatan sentra main peran. Penelitian ini bertujuan untuk mengetahui secara lebih mendalam langkah-langkah yang dilakukan guru TA Al-Manaar Al-Islamiyah Pondok Pesantren Wali Songo Ngabar Siman Ponorogo dalam mengembangkan kecerdasan intrapersonal anak usia dini melalui kegiatan sentra main peran, serta melihat hasil yang telah dicapai dari langkah tersebut bagi pengembangan kecerdasan intrapersonal anak usia dini, dan tak lupa untuk mengetahui kendala atau hambatan yang dihadapi dari penerapan langkah tersebut. Penelitian ini diharapkan mampu memberi masukan atau saran pada guru dalam upaya untuk mengembangkan kecerdasan intrapersonal anak usia dini.

\section{METODE PENELITIAN}

Jenis penelitian ini adalah penelitian kualitatif dengan metode atau pendekatan study kasus (Case study). Jenis penelitian ini digunakan karena penelitian ini terkait dengan kejadian, aktivitas dan kegiatan pengembangan kecerdasan intrapersonal melalui sentra main peran di TA Al-Manaar Al-Islamiyah Ngabar Siman Ponorogo

Peneliti ini dilaksanakan di TA Al-Manaar Al-Islamiyah yang bertempat di Jalan Sunan Kalijaga No. 09 Desa Ngabar Kecamatan Siman Kabupaten Ponorogo. Sumber data primer penelitian ini adalah tindakan dan kata-kata dari informan atau subjek penelitian di TA AlManaar Al-Islamiyah Ngabar Siman Ponorogo yakni kepala sekolah, guru kelas dan guru lainnya yang berperan serta dalam pembelajaran. Sedangkan sumber data sekundernya adalah dokumentasi, diantaranya melalui sumber data tertulis, inventaris serta lain-lain seperti profil sekolah, 
dokumentasi kegiatan anak, dan dokumentasi kegiatan yang pernah dilakukan sebelumnya. Adapun teknik pengumpulan data pada penelitian ini meliputi wawancara, observasi, dan dokumentasi. Teknik analisis datanya menggunakan analisis data kualitatif, yaitu reduksi data, penyajian data, penarikan kesimpulan atau verifikasi data. Yang terakhir pengabsahan data untuk uji kredibilitas data atau kepercayaan terhadap data hasil penelitian ini menggunakan triangulasi dengan memanfaatkan penggunaan sumber (Triagulasi sumber), yakni dari Kepala Sekolah, Guru Kelas TK A dan TK B, dan guru sentra bermain peran.

\section{HASIL DAN PEMBAHASAN}

Berdasarkan hasil penelitian yang telah peneliti lakukan, peneliti akan menguraikan hasil penelitian dengan format deskripsi dari hasil observasi dan wawancara tentang upaya guru dalam mengembangkan kecerdasan intrapersonal anak usia dini dengan cara sentra main peran.

A. Langkah-langkah guru dalam mengembangkan kecerdasan intrapersonal anak usia dini melalui sentra main peran

Sebagian anak menghabiskan waktu belajarnya di kelas selama 4 jam sehari. Bagi anak yang tingkat perkembangan kecerdasan intrapersonalnya tinggi suasana ini sangat membosankan dan menakutkan. Karena itu, guru harus menyediakan kesempatan bagi siswa untuk menikmati dirinya sendiri sebagai pribadi yang unik dan individualis dalam setiap harinya. Seperti di TA Al-Manaar ini guru berperan untuk mengembangkan setiap kecerdasan yang ada di dalam diri anak. Salah satunya guru mengupayakan mengembangkan kecerdasan intrapersonal anak usia dini melalui kegiatan sentra main peran.

Langkah-langkah yang dilakukan guru di TA Al-Manaar AlIslamiyah untuk mengembangkan kecerdasan intrapersonal adalah sebagai berikut: 
1. Guru selalu melibatkan anak secara bersama-sama dalam semua kegiatan sentra.

Dalam pembelajaran sentra guru selalu melibatkan partisipasi anak.Upaya guru dalam mengembangkan kecerdasan intrapersonal anak adalah merangsang minat anak dan selalu melibatkan anak dalam kegiatan sentra. Partisipasi anak dalam kegiatan sentra ini juga disesuaikan dengan karakter atau pribadi anak, agar anak lebih mudah dalam memahaminya (Wawancara lbu Umi Barokahtanggal 19-03-2020). Upaya melibatkan partisipasi anak bersama-sama dalam semua kegiatan sentra tidak lain bertujuan agar kecerdasan intrapersonal anak berkembang dengan baik. Keterlibatan anak dalam kegiatan sentra akan memudahkan mereka untuk berkembang. Hal ini bisa terjadi karena semangat yang mereka dapatkan dengan bersama teman-temannya, dan tentu akan berbeda hasilnya jika anak bermain sendirian.

2. Melibatkan orang tua dalam pembelajaran anak

Dalam pembelajaran, para guru juga melibatkan peran orang tua. Pembelajaran akan berjalan dengan baik jika orang tua juga berperan. Sebagaimana lingkungan belajar utama anak adalah keluarga. Ayah dan ibulah yang berperan dalam pembelajaran anak ketika di rumah. Salah satu cara yang dilakukan TA AL-Manaar ALIslamiyah untuk melibatkan peran orang tua dalam pembelajaran, tercermin dalam kegiatan market day yang dilakukan setahun sekali. Guru melibatkan orang tua dalam menyiapkan kebutuhan anak yang akan digunakan. Para orang tua ditugasi menyiapkan sayuran, lauk pauk, jajanan, bumbu dapur, dan minuman yang semuanya dihargai Rp.1000. Dengan begitu kegiatan berjalan dengan lancar dan anakanak senang(Observasi, Kode: 05/O/17-03/2020). 
Upaya yang dilakukan guru dengan melibatkan orang tua dalam pembelajaran adalah tindakan yang benar dan sangat tepat. Dalam Pendidikan Anak Usia Dini (PAUD) keterlibatan orang tua dalam pendidikan merupakan aspek penting krena orng tua merupakan pendidik pertama dan orang yang pertama kali berinteraksi dengan anak. Keterlibatan atau hadirnya orang tua dapat menjadikan sumber semangat bagi anak dan meningkatkan rasa kepercayaan diri anak.

Bisa menjadi alternatif keterlibatan orang tua dalam pembelajaran, yaitu dengan meminta orangtua melaporkan kegiatan akhir pekan di rumah bersama anaknya. Setelah itu, guru membuat jadwal secara bergiliran mengundang orang tua ke sekolah untuk menceritakan apa saja kegiatan yang telah dilakukan bersama anak mereka. Orang tua dan anak di beri kesempatan secara seimbang untuk bercerita secara bergantian. Kegiatan bercerita tersebut bisa juga ditambahkan dengan orang tua dan anak memperagakan simulasi kegiatan yang mereka lakukan. Anak bisa secara percaya diri berperan memperagakan kegiatn apa saja yang dilakukan bersama orang tuanya. Hal ini tentu upaya yang sangat baik dalam merangsang perkembangan kecerdasan intrapersonal anak.

3. Selalu memotivasi dan memberi semangat kepada anak

Dukungan dan semangat dari guru sangat penting bagi perkembangan anak. Ketika anak melakukan suatu kegiatan atau memerankan tokoh atau peran dalam suatu cerita. Motivasi atau dukungan semangat guru ini sangat berpengaruh dalam menumbuhkan rasa percaya diri anak. Dengan munculnya kepercayaan diri, anak tidak akan minder untuk tampil di depan umum. Hal ini sebagaimana keterangan dari lbu Ita Rahmawati, guru selalu memberikan semangat dan motivasi kepada anak-anak. Terutama 
ketika mereka memainkan perannya dan mereka kurang percaya diri, guru selalu memotivasi anak tersebut. Agar di dalam diri anak tumbuh rasa percaya diri untuk tampil di depan umum (Wawancara Ibu Ita Rahmawati tanggal 20-03-2020).

Dukungan dan semangat dari guru sangat penting bagi perkembangan anak. Ketika anak melakukan suatu kegiatan atau memerankan perannya dalam suatu cerita. Motivasi guru sangat berpengaruh terhadap kepercayaan diri anak. Dukungan tersebut dapat berupa pujian, tepuk tangan, ucapan kebanggaan dan bentukbentuk apresuasi lainnya.

4. Guru berperan sebagai fasilitator dan motivator

Di dalam kegiatan sentra main peran, guru berperan sebagai fasilitator dan motivator. Peran fasilitator yang dilakukan oleh guru adalah menyiapkan segala peralatan yang digunakan dalam sentra bermain peran dan menjadi penghubung antara satu anak dengan anak yang lainnya. sedangkan peran sebagai motivator adalah selalu memberikan semangat dan motivasi, mendampingi dan memberikan pemaknaan terhadap peran yang telah dilakukan oleh anak usia dini setelah selesai bermain di sentra main peran. Hal ini terlihat di kegiatan sentra main peran dengan tema pekerjaanku. Di sana anak-anak berperan sebagai petani ada yang mencangkul dan menanam padi. Guru sebagai fasilitator menyiapkan semua alat-alat yang digunakan untuk anak. Di samping itu guru juga terus memberi motivasi atau semangat kepada anak-anak agar mereka mau memerankan perannya masing-masing dengan tidak ada keterpaksaan. Mereka sangat antusias untuk mengikutinya, meskipun tetap ada beberapa anak yang tidak mau melakukannya(Observasi Kode: 05/O/17-03/2020). 
5. Selalu menyiapkan cerita yang menarik untuk anak pada setiap harinya

Untuk membuat anak-anak tertarik dalam memainkan suatu peran/tokoh, guru harus menyiapkan cerita atau kegiatan yang menarik sesuai tema. Ini sebagaimana keterangan dari lbu Ita Rahmawati. Agar kecerdasan intrapersonal anak berkembang dengan baik melalui kegiatan sentra bermain peran. Guru sentra berusaha menyiapkan cerita atau kegiatan yang menarik untuk anak pada setiap harinya sesuai tema (Wawancara lbu Ita Rahmawati, 20-03-2020).

Agar anak-anak selalu tertarik dalam memainkan suatu peran atau tokoh, maka guru harus menyiapkan cerita atau kegiatan yang menarik. Hal ini dikarenakan anak lebih mudah menerima pemahaman penanaman karakter melalui kisah yang diperankan. Sangat berbeda kisah yang hanya sekedar dituturkan. Kisah yang dituturkan hanya dapat dilihat dan didengarkan oleh anak, namun kisah yang diperankan akan mudah diingat oleh anak akibat dari peran yang ia mainkan bersama dengan teman-temannya.

B. Profil hasil yang telah dicapai dari pengembangan kecerdasan intrapersonal anak usia dini melalui kegiatan main peran

Kecerdasan Intrapersonal dapat berkembang apabila distimulus dengan konsep diri, harga diri, mengenal diri dan percaya diri dan rasa disiplin yang baik. Untuk melihat perkembangan kecerdasan intrapersonal, guru mempunyai beberapa pedoman. Diantaranya adalah kesadaran diri anak dan tanggung jawab anak.

\section{Kesadaran Diri Anak}

Di TA Al-Manaar Al-Islamiyah, perkembangan kesadaran diri anak sudah berkembang dengan baik. Hanya ada beberapa anak yang perkembangannya masih kurang. Hal ini terbukti ketika anak-anak sedang 
bermainsesuai perannya. Mereka sudah bisa menyesuaikan diri ketika harus memerankan salah satu tokoh. Misalnya ketika anak berperan menjadi seorang dokter, mereka benar-benar menikmati perannya dan sangat antusias dalam memainkannya.

Hal ini terjadi setelah guru melakukan beberapa langkah-Zlangkah untuk mengembangkan kecerdasan intrapersonal di sentra main peran, terlihat perkembangan kecerdasan anak, khususnya pada kecerdasan intrapersonal. Seperti hasil wawancara berikut. "Setelah guru menerapkan beberapa langkah-langkah tersebut. Anak lebih tahu kemampuan dirinya dan lebih berani berekspresi untuk mengambil peran yang menonjol pada cerita atau kegiatan di sentra main peran. Anak-anak lebih bisa memerankan setiap peran dalam sebuah cerita, anak-anak juga lebih berani dan percaya diri untuk tampil di depan umum. Selain itu di tengah kemajuan teknologi dan canggihnya gadget banyak anak-anak asik dengan gadget dan dunianya sendiri. Mereka mengalami komunikasi atau sosialisasi yang rendah. Dengan adanya sentra ini kemampuan sosialisasi anak berkembang sesuai perkembangannya (Wawancara Ibu Umi Barokah, 22-03-2020).

Sedangkan di dalam perkembangan lain seperti pengendalian emosi dan kepercayaan pada diri sendiri juga sudah baik. Hanya beberapa anak saja yang emosinya belum stabil, misalnya ketika anak harus berbagi mainan dengan temannya. Kadang anak tidak mau dan suka berebut mainan. Ini menyebabkan anak suka menangis tiba-tiba dan suka marahmarah. Membuat guru harus ekstra sabar dalam menghadapinya dan terus mengembangkan emosi anak agar menjadi baik.

Menurut guru TA Al-Manaar Al-Islamiyah beberapa perkembangan kecerdasan pada anak usia dini lebih mudah dikembangkan di dalam sentra main peran. Karena di dalam sentra main peran termasuk permainan aktif, anak langsung praktik sebagai peran atau tokohnya. 


\section{Rasa Tanggung Jawab Untuk Diri Sendiri dan Orang lain}

Tanggung jawab pada anak sebaiknya ditanamkan sejak dini. Tanggung jawab pada anak bisa menjadi sebuah kebiasaan yang baik. Anak harus belajar bertanggung jawab, supaya kelak anak mampu mempertanggung jawabkan apa yang telah mereka perbuat. Mengajarkan tanggung jawab pada anak sebaiknya dimulai sejak usia dini. Dimana pada usia ini mudah bagi guru, orang tua, masyarakat untuk menanamkannya. Mengajarkan rasa tanggung jawab pada anak harus disesuaikan dengan tahap perkembangannya. Seperti membereskan mainan setelah bermain, merapikan alat-alat tulis, dan meminta maaf ketika berbuat kesalahan.

Ada beberapa indikator tanggung jawab pada anak usia dini yang menjadi pedoman bagi guru dalam mengembangkan kecerdasan intrapersonal anak. Seperti menaati aturan bermain, menyelesaikan tugasnya, meletakkan sepatu dan tas di raknya, membereskan mainan setelah bermain, melakukan perannya ketika bermain, dan menunggu antrian saat bermain.

Di TA Al-Manaar Al-Islamiyah tanggung jawab anak-anak bervariasi ada anak yang sudah mampu bertanggung jawab dan ada juga anak yang belum mampu bertanggung jawab. Seperti pembiasaan pada pagi hari untuk apel pagi. Sebagian anak sudah menaati dengan baik dan tertib tapi beberapa anak belum mau mengikutinya dan malah mainan sendiri. Selain itu pembiasaan seperti melepas sepatu ketika naik ke teras sekolah, masih banyak anak-anak yang melanggarnya. Kadang ada beberapa anak yang masih memakai sepatu sampai ke dalam kelas.

Pembiasaan tanggung jawab pada diri anak sering disipkan dalam sentra bermain peran. Anak diajarkan untuk bertanggung jawab melaksanakan tugas peran yang diterimana dengan baik. Anak yang mampu mendalami karakter tokoh yang diperankannya, akan lebih bisa 
bertanggunng jawab pada dirinya sendiri. Dalam membiasakan tanggung jawab anak, guru TA Al-Manaar Al-Islamiyah melakukan pembiasaan, selalu mengingatkan, mengenalkan hal yang positif dan juga dengan aturan. Hal ini dilakukan terus-menerus agar melekat dalam diri anak, dengan guru terus memberi nasehat dan mengingatkan agar anak lebih memahami dan mengerti.

C. Hambatan yang dihadapi guru dalam mengembangkan kecerdasan intrapersonal melalui kegiatan sentra main peran

Dalam upaya mengembangkan kecerdasan intrapersonal melalui kegiatan sentra main peran, pasti memiliki hambatan. Tak terkecuali apa yang terjadi di TA Al-Manaar Al-Islamiyah. Ada beberapa faktor penghambat,

pertama, kebanyakan anak yang ditunjuk sebagai pemeran merasa pemalu untuk memainkannya. Dengan banyaknya jumlah anak didik dan tentu dengan berbagai macam karakter yang berbeda beda. Ada anak didik yang mempunyai karakter aktif, pemberani dan percaya diri, ada juga anak didik yang pendiam, minder dan pemalu. Hal ini menjadi salah satu permasalahan yang muncul dalam kegiatan sentra main peran. Guru harus bisa memilih karakter atau menempatkan peran yang cocok bagi masing-masing anak didik. Meskipun sudah secara selektif memilah peran yang cocok bagi anak didiknya, masih ada anak yang merasa canggung dalam memainkan peran. Hal ini bisa terjadi karena bermain peran termasuk salah satu jenis bermain aktif yang membutuhkn rasa percaya diri kuat.

Dengan adanya permasalahan ini, guru harus memberi motivasi bagi anak yang masih canggung untuk bermain peran dengan temannya. Motivasi ini bisa dilakukan dengan cara ikut serta dalam kegiatan bermain peran dan mencoba berdialog dengan anak yang masih canggung tersebut, sehingga anak termotivasi untuk menjawab dialog tersebut dan secara langsung sudah ikut dalam sentra main peran. 
Kedua, Kegiatan sentra main peran membutuhkan waktu yang lama. Persiapan dalam kegiatan sentra main peran tidaklah mudah dan harus dipersiapkan dengan matang. Persiapan ini diawali dengan pemilihan tema yang sesuai, pemilihan karakter-karakter yang cocok sebagai tokoh, mempersiapakan atribut-atribut yang akan digunakan. Pada tahap pelaksanan, guru harus memberikan arahan secukupnya, mengkondisikan anak didik sesuai peran yang akan dimainkan. Dan tentu saja bisa dipastikan sentra main peran membutuhkan waktu yang lama. Untuk mensiasati hal tersebut, guru harus mempersiapkan kegiatan sentra main peran sedini mungkin, atau sudah dimasukkan dalam rancangan kegiatan harian dan memilih tema yang mudah serta memiliki waktu kegiatan yang tidak terlalu lama.

Ketiga, kurangnya fasilitas penunjang di dalam sentra main peran. Akibat dari kurangnyafasilitas penunjang ini, ketika anak-anak bermain peran hanya menggunakan atribut atau alat seadanya. Seperti yang dikatakan oleh Ita Rahmawti,Faktor penghambat yang sering dialami guru sentra adalah keterbatasan alat/media yang dimiliki untuk disesuaikan dengan tema. Medianya masih kurang sehingga anak-anak kadang diminta untuk membawa mainan yang mereka punya di rumah, atau jika terpaksa maka menggunakan alat yang sudah ada di sekolah (Wawancara Ibu Ita Rahmawati, 21-03-2020)

Faktor kurangnya fasilitas ini harus menjadi bahan evaluasi bagi pihak sekolah. Untuk menunjang serta memperlancar setiap kegiatan belajar mengajar, tentu pihak sekolah harus menyediakan semua sarana penunjang yang dibutuhkan.

\section{KESIMPULAN}

Dari hasil penelitian ini dapat ditarik kesimpulan bahwa ada banyak langkah yang dilakukan guru untuk mengembangkan kecerdasan intrapersonal anak usia dini melalui kegiatan sentra main peran di TA Al- 
Manaar Al-Islamiyah Ngabar, yang meliput: guru selalu melibatkan anak dalam semua kegiatan sentra, Guru melibatkan orang tua dalam pembelajaran anak, Guru selalu memotivasi dan memberi semangat kepada anak, Guru berperan sebagai fasilitator dan motivator, Guru menyiapkan cerita yang menarik untuk diperankan oleh anak.

Setelah langkah-langkah pengembangan kecerdasan intrapersonal anak usia dini tersebut dilakukan, hasil yang dicapai kecerdasan intrapersonal anak usia dini di TA Al-Manaar Al-Islamiyah Ngabar sudah berkembang dengan baik melalui kegiatan sentra main peran dengan indikator seperti kesadaran diri, pengendalian emosi, menaati aturan, rasa tanggung jawab juga sudah berkembang dengan baik. Rata-rata anak sudah mampu mengendalikan emosi, mentaati aturan dan juga bertanggung jawab. Hanya beberapa anak saja yang belum mencapai tingkat perkembangan itu.

Dalam upaya mengembangkan kecerdasan intrapersonal anak usia dini di TA Al-Manaar Al-Islamiyah menemui beberapa hambatan, di antaranya: kebanyakan anak yang ditunjuk sebagai pemeran merasa pemalu untuk memainkannya, kegiatan sentra main peran membutuhkan waktu lama untuk memainkannya dan kurangnya fasilitas penunjang dalam kegiatan sentra main peran.

Berdasarkan kesimpulan hasil penelitian di atas, maka peneliti mengemukakan beberapa saran, yaitu guru diharapakan selalu memberikan inovasi-inovasi yang menarik dalam setiap kegiatan sentra main peran, agar anak selalu semangat dalam melakukan kegiatan bermain peran, sehingga upaya pengembangan kecerdasan intrapersonal anak dapat berjalan secara maksimal. Selanjutnya, untuk pihak pengelola sekolah diharapkan sebisa mungkin memenuhi sarana prasarana yang dibutuhkan untuk menunjang keberlangsungan dalam kegiatan belajar mengajar. 


\section{DAFTAR PUSTAKA}

Ade Dwi Utami, 2012, "Peningkatan Kecerdasan Intrapersonal Dan Kecerdasan Interpersonal Melalui Pembelajaran Project Approach" Jurnal IImiah Visi P2TK PAUD NI.

Afifudin dan Beni Ahmad Saebani, 2009, "Metodologi Penelitian Kualitatif" Bandung: Pustaka Setia.

Afrizal, 2014, "Metode Penelitian Kualitatif ", Jakarta: Raja Grafindo Persada.

Ahmad Susanto, 2015, "Bimbingan dan Konseling dan Konseling di Taman Kanak-Kanak" Jakarta: Prenamedia Grup.

2017,"Pendidikan Anak Usia Dini Konsep dan Teori”, Jakarta: PT Bumi Aksara.

------, 2011, "Perkembangan Anak Usia Dini Pengantar Dalam Berbagai Aspeknya", Jakarta: Kencana Prenamedia Group.

Ahmad Tabi'in, 2017, "Penerapan Konsep Pembelajaran Berbasis Kecerdasan Majemuk (Multiple Intelligence) pada Anak Usia Dini", Institut Agama Islam Negeri Pekalongan.

Andrianus Krobo, 2014, “Jurnal Pendidikan Anak Usia Dini”, Vol. 8, Edisi 1.

Awlady, 2017, "Pengaruh Bermain Peran Terhadap Kecerdasan Interpersonal Pada Anak Kelas A di TK Buah Hati Makasar", Jurnal Pendidikan Anak Vol.3 https/: www.syekhnurjati.ac.id/jurnal/index.php/awlady.

Dian Asri Pratiwi dan Lailatu Rahma, 2018, "Implementasi Model Pembelajaran Sentra Main Peran untuk Mengembangkan Motorik Halus AUD". http://ejournal.uin-suka.ac.id

Een Y. Haenilah, 2015, "Kurikulum dan Pembelajaran PAUD", Yogyakarta: Media Akademi, 2015.

Evi Muafiah, 2016, "Strategi Pembelajaran Multiple Intelligences di TK/RA Ponorogo", Jurnal $\quad$ ThufuLA vol.4 No.1,https//:www.researchgat.net/publication/329780143

Hanisah, 2014, "Meningkatkan Kecerdasan Intrapersonal Anak Melalui Kegiatan Bercerita Berbantuan Media Film/VCD di Kelompok B5 RA Ummatan Wahidah di Kota Curup, Fakultas Keguruan dan IImu Pendidikan, Universitas Bengkulu. http://digilib. Uinsby.ac.id 
Howard Gardner, 2003, "Multiple Intelligences Kecerdasan Majemuk Teori dalam Praktek", Batam: Interaksara.

Ihsan El-Khuluqo, 2015, "Manajemen PAUD (Pendidikan Anak Usia Dini): Pendidikan Taman Kehidupan Anak", Yogyakarta: Pustaka Belajar.

Iskandar, 2012, “Psikologi Pendidikan”, Jakarta: Referensi.

Jamal Ma'mur Asmani, 2015, "Panduan Praktis Manajemen Mutu Guru PAUD”,Yogyakarta: DIVA Press.

Jamil Suprihatiningrum, 2013,"Guru Profesional Pedoman Kinerja, Kualifikasi,\& Kompetensi Guru", Jogjajkarta: Ar-Ruzz Media.

Julia Jasmine, 2016, "Metode Mengajar Multiple Intelegences, penerjemah dari Julia Jasmine profesional's Guide: Teaching with Multiple Intelegences Teacher Created Materials,Inc. 2001. Bandung: Nuansa.

Khodijah, 2012, “konsep dasar pendidikan prasekolah”, Medan: perdana mulya sarana.

Leli Halimah, 2016, "Pengembangan Kurikulum Pendidikan AUD", Bandung: PT Refika Aditama.

Lexy Moleong, 2017, “Metodologi Penelitian Kualitatif',Bandung: PT Remaja Rosdakarya.

Lia Eka Sari, 2019, "Implementasi model pembelajaran sentra dalam meningkatkan kecerdasan intrapersonal anak usia dini”,Fakultas Tarbiyah dan IImu Keguruan Institut Agama Islam negeri. http:// etheses.iainponorogo.ac.id

Luluk Asmawati, 2014, "Perencanaan Pembelajaran PAUD”, Bandung: PT Remaja Rosdakarya.

May Lwin dkk, 2008, "Cara Mengembangkan Berbagai Komponen Kecerdasan”,Yogyakarta: PT Macanan Jaya Cemerlang.

Muhammad Yaumi dan Nurdin Ibrahim, 2013, "Pembelajaran berbasis kecerdasan jamak”, Jakarta: Kencana Prenadamedia grup.

Muhsinin IImi Navi, 2017, “Efektifitas Pembelajaran Sentra”, STIT NU AI Hikmah. http://jurnal.stitnualhikmah.ac.id

Mukhtar dkk, 2016,"Orientasi Baru Pendidikan Anak Usia Dini Teori dan Aplikasi”,Jakarta:Prenadamedia Group. 
Mukhtar Latif dkk, , 2013, "Orientasi Baru Pendidikan Anak Usia Dini Teori dan Aplikasi.1 FKIP-BK Universitas Cendrawasih. https://media.Neliti.com/media/publication/117495-IDpeningkatan-kecerdasan-intrapersonalmela.pdf.

Muktiono Waspodo, 2012, "Pengembangan Profesional Berkerlanjutan Bagi Guru PAUD”. http://journal.unj.ac.id

Novan Ardy Wiyani, 2015, "Etika Profesi Keguruan, Yogyakarta: Gava Media.

Novi Mulyani, 2016, "Super Asyik Permainan Tradisional Anak Indonesia", Yogyakarta: DIVA Press.

Rina Roudhotul Jannah, dkk., 2018,"Strategi Pembelajaran Anak Usia Dini Berbasis Multiple Intelegences”, Yogyakarta: Ar-Ruzz Media.

Septira Wulandari Alja, 2017, “Upaya meningkatkan kecerdasan intrapersonal melalui sosiodrama pada anak usia dini 5-6 tahun, Universitas Islam Negeri Sumatera Utara Medan. http: // repository.uinsu.ac.id

Sugiyono, 2017, "Metodologi Penelitian Kuantitatif, Kualitatif, dan R\&D”, Bandung: Alfabeta.

Suyadi, 2010, "Psikologi Pendidikan Anak Usia Dini”, Yogyakarta: PT Pustaka Insani Madani.

2014, "Teori Pembelajaran Anak Usia Dini dalam Kajian Neurosains",Bandung: PT Remaja Rosda Karya.

Yuliani Nurani Sujiono dan Bambang Sujiono, 2010, "Bermain Kreatif Berbasis Kecerdasan Jamak”, Jakarta: PT Indeks.

Zakaria Hanafi, 2012, “Implementasi Metode Sentra Dalam Pengembangan Kecerdasan Majemuk Anak Usia Dini", Yogyakarta: Deepublish. 